\title{
Maintaining the Mobility of Motor Cars:
}

\author{
The Case of (West) Germany, 1918-1980
}

\author{
Stefan Krebs
}

Automobiles are not easy, ready-to-use commodities. Motor cars cannot just be bought, driven and eventually sold or scrapped; they are in constant need of regular servicing and, in the event of a breakdown, of repairs in order to preserve their functionality as automobiles. In short, maintenance and repair are "what keeps automobility going". ${ }^{1}$ This was particularly the case in the first decades of mass motorisation, when automotive technology was especially prone to failure, but even today, maintenance and repair are recurring moments in the consumption history of the motor car. However, car repair and repair in general are still largely neglected topics in the history of consumption and technology. ${ }^{2}$

This chapter will use the case of Germany to investigate maintenance and repair as a central part of automobility. ${ }^{3}$ From the perspective of a history of consumption, "mobility" has always been (and still is) at the heart of car consumption. ${ }^{4}$ It is worth noting here that in his book "Short History of the Consumer Society" Wolfgang König described car consumption in the chapter "Mobility

1 Graham, Stephen/Thrift, Nigel: "Out of Order: Understanding Repair and Maintenance", in: Theory, Culture \& Society 24, 3 (2007), p. 1-25, here p. 15.

2 See the next section for a more detailed discussion of repair and car repair in particular in the history of technology and consumption.

3 For the post-war period, I will focus on West Germany. In East Germany, cars did not become a mass consumer product and professional and self-repair practices differed substantially. See Möser, Kurt: "Thesen zum Pflegen und Reparieren in den Automobilkulturen am Beispiel der DDR”, in: Technikgeschichte 79, 3 (2012), p. 207-226.

4 For some car collectors and hobbyist repairers, mobility is not an essential part of consumption practice, but for most ordinary motorists, driving from A to B for professional or leisure purposes is at the heart of automobility. 
and Mass Tourism". 5 A motor car loses its use value as a consumer item, at least temporarily, in the event of a breakdown, ${ }^{6}$ and the exchange value of a broken car decreases when it is sold. So maintenance and repair to prevent or remedy malfunctions have been, and still are, necessary and recurrent moments in the consumption of an automobile. However, car repair also became a leisure activity already in the interwar period and especially in the post-war period, when members of the lower classes started to own automobiles. Self-repair was seen as cheaper than taking a car to a professional garage. Furthermore, self-repair also served as a means to shape and foster male identities as skilled and knowledgeable amateur mechanics, although it was still tied to the idea of restoring the mobility function of motor cars. The chapter will look at these two sides of car repair as the need to maintain the mobility function and the practice of a hobbyist consumer activity that promised status, community and identity.

I will largely draw on published sources from repair manuals, trade journals and consumer magazines to show how and why German motorists either repaired their cars themselves or relied on professional repair services from the beginning of mass motorisation in the 1920s to the more widespread use of car electronics at the end of the 1970s. ${ }^{7}$ To give an overview of the development of car repair in Germany, I will investigate four aspects that framed repair as a necessary part of car consumption: the (un-)reliability of automobile technology; the emergence of a car repair infrastructure; repair costs, which determined to a large extent whether one could afford to drive a car; and DIY repair practices. ${ }^{8} \mathrm{I}$ will argue that the success and widespread adoption of automobiles as consumer products was closely tied to the availability of affordable repair services, and that the emergence of a large-scale car repair infrastructure was a prerequisite for mass motorisation. Kevin Borg has situated car mechanics as occupying a middle ground of technology as they neither produce nor own the cars they repair. ${ }^{9}$

5 König, Wolfgang: Kleine Geschichte der Konsumgesellschaft. Konsum als Lebensform der Moderne, Stuttgart: Franz Steiner 2008.

6 An exception is old cars; see Lucsko, David N.: “"Proof of Life' - Restoration and Old-Car Patina" (this volume).

7 Electronics had a profound impact on car repair as it removed car technology from the realm of motorists and mechanics. See Krebs, Stefan: “Dial Gauge versus Senses 10': German Auto Mechanics and the Introduction of New Diagnostic Equipment, 1950-1980", in: Technology and Culture 55 (2014), p. 354-389.

8 There are many more aspects of car repair that would be worth investigating, like questions of warranty and goodwill or the issue of faulty repairs.

9 Borg, Kevin L.: Auto Mechanics: Technology and Expertise in Twentieth-Century America, Baltimore: Johns Hopkins University Press 2007, p. 1-12. 
However, I will show in this chapter that car repair should in fact be conceptualised as an integral part of car consumption.

\section{CAR REPAIR IN THE HISTORY OF TECHNOLOGY AND CONSUMPTION}

Before I start my historical investigation of German car repair culture in more detail, I will briefly look at the still marginalised role of repair and car repair in the history of technology and consumption. Most historians and sociologists of consumption agree that consumption "involv[es] the selection, purchase, use, maintenance, repair and disposal of any product or service". ${ }^{10}$ In his essay "Beyond Consumerism" Frank Trentmann emphasised that the history of consumption needs to pay more attention to "processes and spaces connected to consumption before and after purchase". " Furthermore, in "Disruption is Normal" Trentmann looked at the impact of electricity blackouts on everyday life and came to the conclusion that "the more consumption, the more breakdown, tension and patchwork". ${ }^{12}$ Despite Trentmann's indisputable achievements in establishing and advancing the history of consumption as a distinct field of historical enquiry, it is telling that maintenance and repair played little to no role in his seminal study "Empire of Things: How We Became a World of Consumers", ${ }^{13}$ even though many modern consumer products could only be consumed because maintenance and repair services were offered concurrently - as the example of automobiles will highlight. ${ }^{14}$ Only in his chapter "Throwaway Society" did

10 Campbell, Colin: “The Sociology of Consumption”, in: Miller, Daniel (ed.): Acknowledging Consumption: A Review of New Studies, London/New York: Routledge 1995, p. 95-124, here p. 100 (italics added).

11 Trentmann, Frank: "Beyond Consumerism: New Historical Perspectives on consumption”, in: Journal of Contemporary History 39, 3 (2004), p. 373-401, here p. 375 (italics added).

12 Id.: "Disruption is Normal: Blackouts, Breakdowns and the Elasticity of Everyday Life", in: Shove, Elisabeth/Trentmann, Frank/Wilk, Richard (eds.): Time, Consumption, and Everyday Life, Oxford/New York: Berg 2009, p. 67-84, here p. 81.

13 "Maintenance" and "Repair" are not listed in the book's index. See Trentmann, Frank: Empire of Things. How We Became a World of Consumers, from the Fifteenth Century to the Twenty-First, London: Allen Lane 2016.

14 For the importance of automobile repair services see e.g. McIntyre, Stephen: "The Failure of Fordism. Reform of the Automobile Repair Industry, 1913-1940”, in: Technology and Culture 41 (2000), p. 269-299. 
Trentmann recognise repair as an important element for a more sustainable consumption of technical objects. ${ }^{15}$ Furthermore, the history of consumption does not acknowledge that self-repairs were also part of consumption and that they played an important role in shaping consumer identities, as the case of the German motorists will show.

The initial purchase of a consumer object such as a motor car - rather than the actual consumption, i.e. driving the car - is often taken as an indicator of the development of consumer markets and practices. The consumer history of the automobile has often adopted this approach, for example when historian Manuel Schramm used the growing number of automobiles to pin down the advancement of modern consumer society. ${ }^{16}$ This purchase-oriented perspective was already being used in the 1920 s to forecast the coming automotive demand and the degree of market saturation by looking at the more advanced spread of other consumer products like the telephone. ${ }^{17}$ In his "Short History of Consumption", Wolfgang König also drew on sales figures for bicycles, motorcycles and automobiles to describe the emergence of German consumer society but he additionally mentioned leisure travel as a form of automobile consumption. He attributed the initially low automotive density in Germany to the low purchasing power of the middle class, without explicitly mentioning the high after-sales costs. ${ }^{18}$ In his essay "The Automobile in Germany", König provided further details, mentioning that annual maintenance costs could represent up to $50 \%$ of the initial purchase price of a car. ${ }^{19}$ For Richard Vahrenkamp the consolidation of the sociotechnical system of the automobile in Germany, including the ever-denser network of petrol stations, roadside assistance, dealers and specialised repair shops, was a precondition for the gradual emergence of mass motorisation in the late 1920 s. ${ }^{20}$ German car manufacturers and service providers adopted the American

15 Trentmann, Empire, ch. "Throwaway Society".

16 Schramm, Manuel: "Konsumgeschichte", in: Docupedia-Zeitgeschichte, URL: docupedia.de/zg/schramm_konsumgeschichte_v2_de_2012 (accessed 19.03.2020).

17 Buschmann, Johannes: "Vorbedingungen der Verkehrsmotorisierung in Deutschland", in: Allgemeine Automobilzeitung (AAZ) 26, 47a (1925), p. 40-43.

18 König, Konsumgesellschaft, p. 173 and 175.

19 König, Wolfgang: "Das Automobil in Deutschland. Ein Versuch über den homo automobilis", in: Reith, Reinhold/Meyer, Torsten (eds.): "Luxus und Konsum" - eine historische Annäherung, Münster et al.: Waxmann 2003, p. 117-128, p. 121; see also McIntyre, "Failure", p. 274.

20 Vahrenkamp, Richard: "Die Rolle von Handel und Dienstleistungen beim Aufbau des 'Systems Automobil' in den 1920er Jahren”, in: Vierteljahrschrift für Sozial- und Wirtschaftsgeschichte 103, 4 (2016), p. 428-451; see also Petersen, Sonja: ““... anner 
slogan of "customer service" as the key to successful mass consumption of automobility. However, Vahrenkamp did not conceptualise the different services as part and parcel of automobile consumption.

While the repair of consumer products has found little attention in the history of consumption, historians of technology have investigated the topic of repair more closely over the past fifteen years. ${ }^{21}$ Car repair has been studied by, among others, Stephen McIntyre, Kevin Borg and the author himself. However, the primary focus of these studies has been car mechanics, professional repair as a socio-technical practice and the mechanic-driver relationship, not maintenance and repair as necessary aspects of automobile consumption. ${ }^{22}$ Kathleen Franz has investigated repair practices of US motorists and automobile tinkering as a form of consumption from about 1900 to $1939 .{ }^{23}$ She stresses the "mechanical ingenuity among the new generation of motor travelers" and that "to drive and repair the machine became tools that consumers used to articulate their varying agendas for greater spatial and cultural autonomy". ${ }^{24}$ Tinkering with automobile technology helped American motorists to construct their consumer identity. ${ }^{25}$ Still, Franz did not look at car repair in detail and instead focused on car accessories and modifications and motorists' inventions.

\section{THE UNRELIABILITY OF EARLY AUTOMOTIVE TECHNOLOGY}

The early motor car was notoriously unreliable. Wolfgang König quotes automotive pioneer August Horch, who claimed that an automobile had to be repaired about every 100 kilometres. ${ }^{26}$ Similar statements from early motorcyclists sug-

Tanke': Tankstellen - ein Forschungsüberblick”, in: Technikgeschichte 83 (2016), p. 71-93.

21 For a more detailed overview see Krebs, Stefan/Weber, Heike: "Rethinking the History of Repair" (this volume).

22 Borg, Auto Mechanics; McIntyre, "The Failure”; Krebs, Stefan: “'Sobbing, Whining, Rumbling' - Listening to Automobiles as Social Practice", in: Karin Bijsterveld/Trevor Pinch (eds.): The Oxford Handbook of Sound Studies, Oxford/New York: Oxford University Press 2012, p. 79-101; id., "Dial Gauge".

23 Franz, Kathleen: Tinkering: Consumers Reinvent the Early Automobile, Philadelphia: University of Pennsylvania Press 2005.

24 Ibid., p. 1 and 3.

25 Ibid., p. 11.

26 König, Das Automobil, p. 118. 
gest that an hour of driving was followed by another two hours of tinkering. ${ }^{27}$ Even if Horch slightly exaggerated the error-proneness of automobiles it was for good reason that early car owners usually employed chauffeur-mechanics: "The chauffeur, a learned mechanic, maintain[ed] the complicated mechanism of the motor car and ke[pt] it ready for a ride." ${ }^{28}$ It is also telling that the most popular German handbook for self-driving motorists was called "Without a Chauffeur" (Ohne Chauffeur). The author emphasised that a good driver had to acquire not only driving aptitude but also extensive repair knowledge and skills, much like a chauffeur-mechanic. ${ }^{29}$

While only a few well-off German motorists took to the wheel themselves before the First World War, German automotive journalists started a lively discussion after the war about the aspiration to mass motorisation in Germany. Most contributors agreed that the susceptibility to defects was one of the major obstacles that hampered upper-middle-class people from owning an automobile. In other words, increasing the reliability of affordable automobiles was seen as an essential prerequisite for mass motorisation. ${ }^{30}$ The well-known automotive journalist Berger von Lengerke stated: "First of all and most importantly, these cars have to be constructed in such a way that they can be driven without a mechanic." 31 He also offered several suggestions as to how to design better cars, e.g. through the replacement of wood by sheet metal for the construction of the body, or the reduction of the number of lubrication points. The latter principle would be more convenient for drivers and offer more robustness. ${ }^{32}$ Other trade

27 Lützen, Wolf Dieter: "Radfahren, Motorsport, Autobesitz. Motorisierung zwischen Gebrauchswerten und Statuserwerb", in: Ruppert, Wolfgang (ed.): Die Arbeiter: Lebensformen, Alltag und Kultur von der Frühindustrialisierung bis zum “Wirtschaftswunder", Munich: C. H. Beck 1986, p. 367-377, here p. 370. Other consumer products like colour TVs were similarly error-prone in their early days. See Weber, Heike: "Mending or Ending? Consumer Durables and Practices of Reuse, Repair and Disposal in West Germany, 1960s-1980s" (this volume).

28 Friedmann, P.: "Der Kraftwagen des Selbstfahrers", in: AAZ 26, 41 (1925), p. 25; see also the chapter "The Problem with Chauffeur-Mechanics" in: Borg, Auto Mechanics.

29 Filius [Schmal, Adolf]: Ohne Chauffeur: Ein Handbuch für Besitzer von Automobilen und Motorradfahrer, Berlin: Klasing 1919.

30 In the US, the Ford Motor Company desperately tried to improve maintenance and repair services between 1913 and 1925 as a reaction to growing customer dissatisfaction with error-prone cars. See McIntyre, "The Failure".

31 Lengerke, Berger von: “Zeitgemäße Konstruktions-Richtlinien”, in: AAZ 20, 15 (1919), p. 11-13, here p. 11.

32 Ibid., p. 13. 
authors agreed that motor cars should no longer be elitist sports machines that could not be driven over longer distances without a mechanic on board: "He [the self-driving motorist] should be able to regulate and maintain all mechanical parts, at least those in need during a ride, without getting his hands dirty." 33

German automotive manufacturers indeed introduced several technical innovations that facilitated operation and maintenance, e.g. electric starters. While in 1918 most cars still had manual starters, by 1922 67.7\% of all new cars were equipped with electric starters, and the following year the figure increased to $82.5 \% .{ }^{34}$ At the same time, in the space of a few years the open car body was replaced by the closed sedan, "Innenlenker" in German, a body type that simplified year-round operation. This development went hand in hand with the substitution of wooden bodies with sheet metal bodies that increased the durability of motor cars. ${ }^{35}$

For the interwar period, it is difficult to find figures on the susceptibility to defects or breakdown frequency of motor cars. While we do not have data from Germany, 1926 figures from the British Royal Automobile Club reveal the most common causes of breakdown, and we can assume that German and British car technology was relatively similar at that time. The numbers came from the club's "get you home service", a tow-away service for broken down cars. As the club had to pay for each operation, an expert had to investigate every case and report the technical cause, and this information was added to the club's own breakdown statistics. The figures, not including accidents, revealed that the main source of problems was the ignition with $22.7 \%$, followed by the rear axle with $12.4 \%$, cylinders and pistons with $6.9 \%$, tyres and suspension with $6.1 \%$, and the drive shaft with 5.1\%. ${ }^{36}$ The American Automobile Association also published a breakdown of statistics in 1928. The figures came from 14 regional clubs offering roadside assistance. The numbers, based on 32,993 calls from motorists in distress, showed the main source of problems to be the battery and starter, with $22.3 \%$, followed by tyres with $20.7 \%$. The other categories were not comparable with the British survey: $20.3 \%$ of engines would not start, $17.2 \%$ of cars had to

33 Friedmann, “Der Kraftwagen”, p. 25.

34 Dierfeld, Benno R.: "Deutscher Kraftfahrzeugbau im Jahre 1923", in: AAZ 24, 12 (1923), p. 27-29.

35 Krebs, Stefan: "The French Quest for the Silent Car Body: Technology, Comfort and Distinction in the Interwar Period", in: Transfers: Interdisciplinary Journal of Mobility Studies 1, 3 (2011), p. 64-89.

36 Witte: "Welches sind die häufigsten Reparaturen am Kraftwagen?", in: AAZ 27, 33 (1926), p. 16. 
be towed away, and $5.9 \%$ of problems were attributed to unspecified causes. ${ }^{37}$ Unfortunately, the British and American statistics do not include information about the age of the cars or the average mileage.

While we do not have comparable figures from Germany, trade journals frequently discussed the unreliability of current automotive technology and they argued for a design principle that would take repairability more seriously. In particular, parts that had to be readjusted frequently, like valves, should be easily accessible for motorists. This was clearly not always the case, and articles about the new models for the coming season were critical of those that did not prioritise a repair-friendly design. One journalist said: "In my opinion, it would be strongly advisable for car engineers not only to work in the design office but also in practice, with a manufactured car, to try to disassemble what they have designed. This would result in many designs being changed once the responsible designer, hands aching, realises how unnecessarily difficult such a job can be." 38

\section{IN NEED OF REGULAR REPAIRS: USER SURVEYS FROM THE 1960s AND 1970s}

Although the National Socialists promoted mass motorisation after they seized power, actual developments lagged behind expectations, and the Second World War put all ideas of private automobility and worries about unreliable cars on the backburner. But by around 1950, automobile production and automobility in West Germany had recovered from the effects of the war; they soon returned to the level of the interwar years, and the 1960s and 1970s witnessed unprecedented growth in car production and ownership. During the recovery phase, repairability remained an important topic. Test reports of new models regularly discussed the accessibility of batteries, carburettors and air filters - components that needed regular maintenance and readjustment. ${ }^{39}$ Automobile manufacturers also investigated how to increase the reliability of new cars. During the winter of 1955, BMW organised long-distance test drives of several models to document wear and tear. They invited a group of ordinary motorists to drive each car around $30,000 \mathrm{~km}$ under a range of challenging weather and driving conditions.

37 Anon.: "Amerikanischer Straßendienst für Kraftfahrzeuge”, in: AAZ 29, 10 (1928), p. 43-44.

38 Kink: "Moderne Kraftwagen und deren Reparatur", in: AAZ 26, 48b (1925), p. 28.

39 See e.g. Anon.: "Die ADAC Motorwelt fuhr: den Mercedes-Benz Typ 180", in: ADAC Motorwelt 6 (1953), p. 629-631. 
Technicians then checked the performance of all the technical components that were known to cause technical problems. ${ }^{40}$

For many motorists, reliability was also an important reason to buy a particular brand or model. In the late 1960s, customers of the new mid-range VW 1500, for example, named in a market survey the following main reasons for purchase: $51 \%$ cost effectiveness, $44.3 \%$ steadiness, $32.5 \%$ robustness and longevity, and $32.2 \%$ good customer service. ${ }^{41}$

A more systematic investigation of the actual weaknesses of automobiles started at the end of the 1960s. The club magazine of the ADAC, the largest German automobile club, invited its readers to take part in "Field Test" (PraxisTest) surveys. Owners of specific models were invited to fill out detailed questionnaires about their experience with petrol consumption, the life span of tyres, regular maintenance services and unexpected breakdowns, and in the event of malfunctions to list which parts were affected. This is quite remarkable as it shows that users were systematically involved in defining and evaluating the actual maintenance needs of automobiles. In the first test 1,733 owners of five mid-range car models, e.g. the Ford $17 \mathrm{M}$ and the Renault 16, took part. The cars had an average mileage of $25,813 \mathrm{~km}$. The published results revealed, for example, that drivers of a Renault 16 had to visit a workshop for repairs 1.2 times between regular maintenance services, compared with 2.8 times for drivers of a Fiat 125 . In general, the parts most susceptible to malfunction were the engine, carburettor, cooling system, exhaust pipe and clutch. However, the survey revealed considerable differences between car models: $60 \%$ of Fiat $125 \mathrm{~s}$ had problems with the exhaust, compared to $11 \%$ of Renault $16 \mathrm{~s} ; 32 \%$ of Opel Rekords had problems with the clutch compared to only $5 \%$ of Ford $17 \mathrm{Ms} .{ }^{42}$ From these results, we can deduct that the reliability of the ignition, starter and battery, the components that caused most problems during the interwar period, seems to have increased, as they are no longer listed in the first field test. However, this was only true for mid-range cars, as another survey showed. This time small cars like the popular VW 1200 were tested. While the overall reliability was comparable with that of larger cars - drivers of a Simca 1000 LS had to see a mechanic 1.3 times between services, owners of a Fiat 859 N 2.6 times -, different components caused trouble: the engine, starter, generator, ignition and carburettor. ${ }^{43}$

40 K.W.: "Versuchsauftrag 88", in: ADAC Motorwelt 8 (1955), p. 66-67.

41 Anon.: "VW 1500: Schwarzbrot aller Klassen", in: Der Spiegel 50/1968, p. 110.

42 MC: "Leser-Bilanz nach 45 Millionen km", in: ADAC Motorwelt 23 (1970), p. 4048.

43 Lotz, Heiner: "Nach 40 Millionen km”, in: ADAC Motorwelt 24, 11 (1971), p. 60-71. 
And 1978 figures from the ADAC roadside service showed yet another list of unreliable car parts: cable connectors, throttle cable, breaker contacts and fan belts were to blame for one in every four breakdowns. ${ }^{44}$ So it is difficult to estimate which parts of automotive technology became more reliable over time and which troubled car drivers all the time. Before I conclude this section, it is interesting to note that the 1977 field test of medium-sized cars revealed that a Japanese car, the Toyota Corolla, was significantly more reliable than the other cars tested. On average, Corolla owners had to see a mechanic only 0.5 times between services; no other car tested had a figure below 1 in the $1970 \mathrm{~s}^{45}$ The reliability of Toyota was also reflected in roadside service figures and the brand became known for its quality.

Susceptibility to breakdown and the frequency of malfunctions significantly influenced the possibility or impossibility of car consumption. Early motor cars were so error-prone that driving without a mechanic on board was difficult. Trade journalists urged manufacturers to produce more reliable cars to convince more customers to buy an automobile, but field tests from the 1960s and 70s show that technical problems were still inherent to car mobility. In the following section I will look at the emergence of a (roadside) repair infrastructure that helped car drivers to cope with unreliable automobiles.

\section{THE EMERGENCE OF AUTOMOBILE REPAIR INFRASTRUCTURE}

As seen in the previous section, the unreliability of motor cars jeopardised the consumption of (auto-)mobility - and not only in the early years. When driving, and especially outside larger cities, motorists had to be prepared to deal with smaller and larger malfunctions at any time. Before the First World War, when most automobiles were driven by chauffeurs, a mechanic was always on board, because chauffeur-mechanics were trained to drive and to repair a motor car on the road if necessary. This is also why motor cars were equipped with a large

44 Id.: "Diese vier Teile waren an jeder vierten Panne schuld", in: ADAC Motorwelt 31 (1978), p. 10-19.

45 Id.: "Vier Europäer und ein Japaner. Er war der Zuverlässigste", in: ADAC Motorwelt 30, 4 (1977), p. 42-46. 
tool set and some spares of parts that were well known for causing problems. ${ }^{46}$ At home, the garage was also a workshop where chauffeurs could carry out major repairs in addition to regular maintenance, cleaning and greasing. In many cases, larger rental garages offered a parking space together with the necessary tools, parts and work areas for all kinds of repair work. ${ }^{47}$ If the chauffeur could not repair the car himself, it had to be towed to the specialist workshop of a car dealer or manufacturer. Independent professional auto mechanics only gradually emerged out of traditional trades like blacksmiths, fitters and other metalworkers. $^{48}$

In the interwar period, the motoring press praised self-driving as a new ideal. Manufacturers and trade journalists agreed that mass motorisation could only really get going in Germany if members of the middle class took to the wheel, and they had to do so themselves, as they did not possess the financial means to employ a chauffeur. However, this new practice required one of two things: either drivers had slip into the role of chauffeurs and drive and repair their cars themselves, or substantially more maintenance and repair services had to be offered to help drivers with breakdowns on the road. Both options were discussed at length in the motoring press: self-driving motorists were urged to acquire the necessary knowledge and skills to repair their automobiles, and the automobile business was advised to offer more and better services. In 1925, for example, an article in the "General Automobile Newspaper" (Allgemeine Automobil-Zeitung, hereafter AAZ) argued not only that road conditions and traffic signs needed to be improved and expanded, but that more service stations and other auxiliary facilities were urgently needed to ease the increase in automobile consumption, e.g. a pick-up and delivery service for workshops or a maintenance subscription service. Furthermore, petrol stations, garages and workshops had to learn to offer a real "service to the customer", as emphasised in the United States. This plea partly came in response to a rise in complaints from motorists about faulty repair jobs and excessive bills. ${ }^{49}$

During the 1920s, the network of professional maintenance and repair businesses in Germany became denser. At the end of the decade, about 20,000 spe-

46 Krebs, “'Notschrei eines Automobilisten' oder die Herausbildung des deutschen KfzHandwerks in der Zwischenkriegszeit”, in: Technikgeschichte 79, 3 (2012), p. 185206; see also Borg, Auto Mechanics, ch. "The Problem with Chauffeur-Mechanics".

47 Anon.: "Betriebsorganisation von Großgaragen", in: AAZ 26, 28 (1925), p. 45; Vahrenkamp, "Die Rolle".

48 Krebs, "Notschrei"; Borg, Auto Mechanics.

49 Buschmann: "Vorbedingungen der Verkehrsmotorisierung in Deutschland", in: AAZ 26, 47a (1925), p. 42. 
cialised auto repair shops offered their services for a fleet of 420,000 cars. ${ }^{50}$ In addition, the automotive trade underwent a process of professionalisation, as I have shown elsewhere, ${ }^{51}$ and founded its own trade guilds, with apprenticeship schemes and mandatory exams to improve and secure the qualification level of auto mechanics. After coming to power in 1933, the National Socialists promoted the still stagnating mass motorisation of Germany. To this end, they established a legal framework of compulsory auto mechanics guilds and only permitted repair shops to be opened by qualified master craftsmen. The argument for the introduction of these measures was that the difficult relationship of trust between motorists and mechanics was preventing too many prospective motorists from buying an automobile, and the new system would encourage these people to take the leap and actually purchase their own car.

In addition to the emergence of a network of professional repair shops, automobile clubs and dealer associations started the first roadside repair and towaway services in the late $1920 \mathrm{~s}^{52}$ In the autumn of 1927 , for example, the ADAC decided to set up and operate a first roadside assistance service the following year. A small fleet of 40 motorcycles, cars and light trucks patrolled main roads to help motorists in distress - all motorists, but club members were given priority. In addition, the ADAC set up a line of telephone boxes along main roads that drivers could use to call for help if they were experiencing technical problems. In contradiction to their announcement that they would foster mass automobility, the National Socialists forced the German automobile clubs to stop their roadside assistance systems in $1933 .^{53}$

After the war, the ADAC decided to re-establish a road service in 1951. As a first step, the motor club established contracts with 3,000 repair shops. The commissioned auto mechanics offered members a free roadside assistance and tow-away service. However, most shops were located close to main roads and motorways. ${ }^{54}$ To provide help away from the main road network, the ADAC encouraged skilled members to join the club's volunteer service. These volunteers

50 Krebs, "Notschrei”, p. 194.

51 Ibid., p. 198-201.

52 Vahrenkamp, "Die Rolle".

53 Anon.: "ADAC-Strassenwacht", in: ADAC Motorwelt 6 (1953), p. 711. From the available sources, it is not clear what motivated that move. In 1933, the National Socialists forced all existing German automobile clubs to merge into the new German Automobile Club (DDAC). The discontinuation of roadside services may have been part of that restructuring process. See Fack, Dietmar: Automobil, Verkehr und Erziehung, Wiesbaden: VS Verlag 2000, p. 326-327.

54 Anon.: “ADAC-Strassendienst”, in: ADAC Motorwelt 4 (1951), p. 10. 
had a sticker on their cars and promised to help fellow motorists. In 1953, there were about 7,500 such volunteers who reported more than 21,500 cases of assistance, ${ }^{55}$ two years later, more than 23,000 volunteers reported some 30,000 repair services. ${ }^{56}$ At about the same time, the ADAC re-introduced roadside patrols. ${ }^{57}$ Initially, 60 club mechanics with sidecar motorcycles equipped with tools and spare parts patrolled the roads. For the year 1955, the club proudly reported that the roadside mechanics had repaired some 150,000 motor cars. ${ }^{58}$ The ADAC gradually expanded its assistance network in the following decades, and other motor clubs offered similar services, too.

In the field of professional auto mechanics, it is noteworthy that the number of independent repair shops diminished during the 1940s. ${ }^{59}$ In 1949, some 15,000 workshops with 100,000 mechanics took care of one million vehicles (including commercial vehicles). By 1966, the number of workshops had increased slightly to 18,400 , but at the same time the number of cars had soared to twelve million. ${ }^{60}$ The lower ratio of repair shops to automobiles led to longer waiting times for a workshop appointment and unsatisfactory service quality. The conviction that bad repair jobs were not only a subjective judgement by motorists led to a large-scale assessment of repair shops by the ADAC in collaboration with the popular magazine Stern. In 1970, six specially prepared cars with ten built-in faults were sent to 120 different garages. The idea was that a good regular maintenance service should find and fix all malfunctions such as a burntout headlight bulb. However, on average only $59 \%$ of the work was done during the planned maintenance service. ${ }^{61}$ Five years later, only one workshop out of another 120 tested fixed all the faults. ${ }^{62}$ The workshop tests highlight the important role of automobile clubs as mediators between producers and consumers. The test reports sparked a public debate about poor repair services and led to

55 Anon.: “Ausbau der ADAC-Leistungen”, in: ADAC Motorwelt 6 (1953), p. 367.

56 Bretz, Hans: "Die Armee des Friedens”, in: ADAC Motorwelt 9 (1956), p. 706-707.

57 Anon.: "Die ADAC-Strassenwacht", in: ADAC Motorwelt 6 (1953), p. 617.

58 Bretz, "Die Armee des Friedens".

59 From the available sources it is unclear whether this was an impact of the war or if the sector was consolidated for economic reasons.

60 Anon.: "Reparaturen müssen so teuer sein", in: ADAC Motorwelt 19 (1966), p. 4248. In 1960, the number of car mechanics was 179,000, in 1970 226,000. Krebs, "Dial Gauge", p. 368.

61 MC: "Von 10 Inspektions-Arbeiten nur 6 gemacht!", in: ADAC Motorwelt 23, 5 (1970), p. 38-48.

62 Caroselli, Manfred: "Diese 6 Wagen waren in 120 Werkstätten zur Inspektion”, in: ADAC Motorwelt 28, 4 (1975), p. 4-10. 
some changes in the legal framework that made it easier for motorists to check their workshop bills and identify any unsatisfactory or overpriced repairs. Manufacturers drew another conclusion: they saw the main cause of the workshop problems as being the poor ratio of mechanics to automobiles and introduced new tools and devices for the rationalisation of diagnostic and repair work. Volkswagen, for example, introduced a standardised service check with some semi-automatic tests in 1968, followed by a "computer diagnosis" in 1971. The latter was an attempt to fully automate checks on 88 parts and functions to eliminate the error-prone human factor in car diagnostics - with little success. Volkswagen abandoned the computer diagnosis after receiving numerous complaints from customers and mechanics for several years. ${ }^{63}$

To sum up, the establishment and expansion of a repair infrastructure with professional repair shops, tow-away and distress call services and roadside assistance helped more and more people take to the wheel, despite the prevailing unreliability of automobiles. While basic technical knowledge and skills, as well as tools and spare parts, were still a necessity in the interwar years to drive outside larger cities, better infrastructures enabled less knowledgeable and skilled motorists to use their automobiles without worrying too much about a possible breakdown on the road. From the late 1950s onwards, ownership of automobiles in West Germany increased on average by 850,000 cars every year. However, this reassurance came at a price, for example the yearly membership fees for an automobile club. In 1962, ADAC membership cost around 31.70 DM while the monthly average income was $610 \mathrm{DM}^{64}$

\section{THE DEVELOPMENT OF AUTOMOBILE REPAIR COSTS}

While the membership fee for an automobile club seemed reasonable for people with an average income, at least in the 1960s, the cost of maintenance and repair had a more decisive impact on whether people could afford to own a car at all. Although we lack exact figures for the first 50 years of automobile consumption

63 Krebs, Stefan: "Diagnose nach Gehör? Die Aushandlung neuer Wissensformen in der Kfz-Diagnose (1950-1980)", in: Ferrum 86 (2014), p. 79-88; for early attempts to rationalise car repair work see McIntyre, "Failure".

64 Motor clubs in other European countries also offered similar services to motorists, see e.g. Anon.: "Panne im Urlaub?", in: ADAC Motorwelt 26, 6 (1973), p. 136-142. For the average income in 1962 see Bundesgesetzblatt I, Cologne: Bundesanzeiger 2002, p. $869-870$. 
in Germany it is safe to argue that high maintenance costs hampered mass consumption of cars until the 1950s. This section will take a closer look at the development of these maintenance costs. One problem in doing so is not only the lack of detailed numbers but also the definition of maintenance costs in general. Broadly speaking, maintenance costs include all steady and usage-dependent costs to keep an automobile running, i.e. taxes, rent for a garage, fuel and tyre consumption, costs of technical services and repairs. However, the sources do not always indicate which costs are included or excluded from the numbers given. This can make it particularly difficult to estimate the costs for technical services and repairs that are of interest for this section.

An article in the AAZ stated in 1919 that before the war a self-driving motorist had to pay 28-30 pfennigs per kilometre for a small $5 \mathrm{HP}$ car. With an annual mileage of 10,000 kilometres, this came to about 3,000 RM per year, with such a car costing around 4,500 RM to purchase. ${ }^{65}$ So for a small car, maintenance costs amounted to two-thirds of the purchase price, while the average annual income was 2,010 RM. ${ }^{66}$ However, the article stated that such a small car "was quite affordable for middle-class white-collar workers" ${ }^{67}$ After the First World War, the goal of mass consumption of automobiles did not come to fruition in Germany. One important reason was the declining purchasing power of the middle classes because of the wartime and post-war inflation, which pushed car ownership out of reach. ${ }^{68}$ Still, the automobile stock in Germany had doubled in 1922 compared to $1914 .{ }^{69}$ However, only a small wealthy class could afford car ownership; it is telling that around $50 \%$ of cars at that time were still driven by a chauffeur. $^{70}$

Another article from 1922 revealed that the majority of usage-dependent costs were not attributed to tyre wear or fuel but to buying spare parts to replace worn-out components. ${ }^{71}$ The high repair costs sparked a debate about the unsatisfactory relationship between initial purchase and follow-up repair costs. One

65 Lengerke, Berger von: “Kleinautos und kleine Wagen”, in: AAZ 20, 40 (1919), p. 1920.

66 Bundesgesetzblatt I (2002), p. 869-870.

67 Lengerke, "Kleinautos", p. 19.

68 Feldman, Gerald D.: The Great Disorder. Politics, Economics, and Society in the German Inflation, 1914-1924, New York/Oxford: Oxford University Press 1993.

69 Anon.: "Die Automobile der Welt", in: AAZ 23, 51, 52 (1922), p. 28.

70 Anon.: "Die Zählung der Kraftwagen”, in: AAZ 23, 23 (1922), p. 31-32; Vahrenkamp, "Die Rolle".

71 Freiherr v. Löw: “Kleine oder große Wagen?”, in: AAZ 23, 16 (1922), p. 29. 
journalist accused manufacturers of building cheap but repair-unfriendly automobiles:

"Such a car will be cheap. However, because the design only took into consideration the market price and not use and maintenance it is likely that you will have to remove the whole engine and the cylinders even if you only want to change a worn out connecting rod bush. [...] So what is the point of producing a cheap car if at the slightest malfunction and repair the owner starts to hate it?"72

In addition to this discussion about construction principles and repairability, we can learn more about the overall lifespan of motor cars from a survey carried out in the United States in the mid-1920s. The survey revealed that automobiles lasted only seven years, and that the average car was about three years old. ${ }^{73}$ These figures, even if they might have been slightly different in Germany at the time, suggest that the repairability of automobiles was rather limited and that increasing maintenance costs made older cars uneconomical within a few years. Or, in other words, car consumption required the purchase of a factory new car every three to seven years. ${ }^{74}$

Another type of source, advertisements, also points to the importance of low maintenance costs for potential buyers. From the 1920s onwards, the economic aspects of car ownership became an important advertising slogan for manufacturers. In particular, small cars were advertised for their low maintenance costs. The Wanderer campaign in 1922 praised its "exceptional economy" that enabled "cheap business travel and commuting". ${ }^{75}$ A few years later, Opel claimed that the new 4 HP model was the "most economical car in the world". 76

In the post-war period, in particular from the late 1950s, when car ownership came within reach of the lower middle class and the working class, manufacturers of small and medium-sized cars continued to advertise the low maintenance costs of their models. In 1965, Volkswagen announced in an advertisement that "the most economical thing about a Volkswagen is how long it is economical", and went on to claim that "at VW, even the repairs are economical". ${ }^{77}$ It is hard-

72 Wa. O.: “Technischer Komfort bei Kraftfahrzeugen”, in: AAZ 24, 40 (1923), p. 38.

73 Anon.: "Die Lebensdauer des Automobils", in: AAZ 27, 28 (1926), p. 26.

74 The short lifespan of cars was also an important factor in explaining why second-hand markets did not really emerge before the post-war period.

75 Wanderer: advertisement, in: AAZ 23, 7 (1922), p. 37.

76 The 4 HP Opel cost 2,800 RM, with an annual tax of 150 RM. Opel 4 PS: advertisement, in: AAZ 28, 36 (1927), p. 41.

77 VW: advertisement, in: ADAC Motorwelt 18, 1 (1965), p. 31. 
ly surprising that market research surveys found that maintenance costs were a key factor for customers of small and mid-range cars. In the case of the VW 1500 , for example, $51 \%$ of buyers in 1968 pointed to "cost-effectiveness" as the main reason for buying, followed by "reliability" with $44.3 \%{ }^{78}$ Furthermore, manufacturers like Ford emphasised that they did not sell "throw-away car[s]"; this was presumably a pre-emptive reaction to the impending debate over planned obsolescence. ${ }^{79}$

From the 1950s on, we have more detailed figures about maintenance costs. Automobile clubs like the ADAC started to regularly publish calculations of various cost items. For 1953, these figures showed that the fixed costs of a VW Standard amounted to 1,994 DM per annum and the running costs per $100 \mathrm{~km}$ to $10.68 \mathrm{DM}$. At the previously assumed mileage of $10,000 \mathrm{~km}$ this amounted to 1,068 DM. For repairs only, including spare parts and a reserve for a major overhaul, the ADAC calculated 2.50 DM per $100 \mathrm{~km} .{ }^{80}$ Considering that the average annual salary was 4,061 DM, it is clear that car ownership was still out of reach for most people. ${ }^{81}$ Twenty years later, the calculated repair costs for a VW 1300 had doubled to $5.55 \mathrm{DM}$ per $100 \mathrm{~km}$, but the average salary had more than quadrupled to $18,295 \mathrm{DM}^{82}$ Thus automobile consumption had come within reach of the lower middle class.

In addition to calculated repair costs, we can find figures of actual repair costs from motorists. Starting in 1955, club members were regularly asked to report their repair and maintenance costs to the club journal. These surveys revealed that actual repair costs were initially still slightly higher than the calculated costs. In 1955, for example, owners of cars with a 1,200 cc engine reported to the $A D A C$ Motorwelt that they had paid on average $3 \mathrm{DM}$ per $100 \mathrm{~km}$ for repairs (calculated on the basis of an annual mileage of $10,000 \mathrm{~km}$ ). ${ }^{83}$ In 1971, a similar survey showed that the average repair costs for a VW 1200 had dropped to 1.10

78 Anon., "VW 1500".

79 Ford: advertisement, in: ADAC Motorwelt 29, 5 (1976), p. 43; on the debate over obsolescence see Weber, Heike: "Made to Break? Lebensdauer, Reparierbarkeit und Obsoleszenz in der Geschichte des Massenkonsums von Technik", in: Krebs, Stefan/Schabacher, Gabriele/Weber, Heike (eds.): Kulturen des Reparierens: Dinge Wissen - Praktiken, Bielefeld: transcript 2018, p. 49-83.

80 Wa.: "Was mein Wagen kostet", in: ADAC Motorwelt 6 (1953), p. 61-62.

81 Bundesgesetzblatt I (2002), p. 869-870.

82 Anon.: "Autofahren war noch nie so teuer", in: ADAC Motorwelt 26, 4 (1973), p. 70 73; Bundesgesetzblatt I (2002), p. 869-870.

8380,000 members took part in the survey. Anon.: "Ihr Wagen in der Statistik", in: ADAC Motorwelt 9 (1956), p. 584-585. 
DM per $100 \mathrm{~km}$, which is only one fifth of the calculated repair costs, as shown above. ${ }^{84}$ It is difficult to interpret the different figures because the sources do not always give all the details of what was included in repair costs. It is likely, for example, that car owners did not include a reserve in their reported costs. However, we can conclude that, from the late 1960s onwards, maintenance and repair costs increased at a much slower rate than the average salary, so automobile consumption generally became much more affordable. Still, repair costs were a significant cost item and, as we will see in the following section, many motorists preferred to repair their cars themselves, as they considered it less expensive.

\section{DIY REPAIR AND AUTOMOBILE CONSUMPTION}

As we have briefly discussed in previous sections, motorists started to repair their cars themselves long before the 1960s. Initially it was the lack of professional garages and other repair infrastructures that forced motorists without a chauffeur to self-repair. To acquire the necessary technical knowledge car drivers could consult a wide selection of manuals and self-help books. The wellknown instruction book "Without a Chauffeur" was published in 13 editions between 1904 and 1930. ${ }^{85}$ In addition, special repair guides offered systematic overviews of possible faults and their causes or guidelines on how to use one's senses to diagnose e.g. visible or audible symptoms. ${ }^{86}$ Journals published similar self-help articles and advised motorists on useful tools and spare parts that should be taken on board for longer trips. ${ }^{87}$ Hundreds of letters to the AAZ, a selection of which was regularly published in the "letterbox" column, testify to the numerous DIY repairs that were being carried out. It is interesting to note that the various repair manuals and readers' letters seldom mentioned economic reasons for self-repair. Motorists repaired their cars out of necessity or when they distrusted ad-hoc mechanics. The latter was often the case before car mechanics started to professionalise their trade in the late $1920 \mathrm{~s} .{ }^{88}$

84 Lotz, "Nach 40 Millionen km".

85 The first editions were entirely dedicated to motor cyclists.

86 See e.g. König, Adolf: Das Automobil und seine Behandlung, Berlin: R.C. Schmidt 1919; Heßler, Rudolf: Der Selbstfahrer, Leipzig: Hesse \& Becker 1926.

87 See e.g. Schur, Rolf: “Werkzeugergänzung für Kraftwagen”, in: AAZ 29, 44 (1928), p. 18.

88 The term "ad-hoc mechanic" has been coined by Kevin Borg to describe the numerous fitters, blacksmiths etc. that became car mechanics without special training at the 
However, the bourgeois self-drivers of the interwar years perceived selfrepair not only as a technical burden but also as a welcome means of social distinction. It enabled them to imitate the automobile consumption of the rich automobile pioneers, for whom mishaps and their elimination were an inherent part of the automobile adventure. Moreover, the new class of self-driving motorists were able to demonstrate their mastery of modern technology and prove their group affiliation by publicly self-repairing. Andrea Wetterauer interprets the demonstrated enthusiasm for and associated pride in self-repairing as an essential aspect of the bourgeois automobile culture of the 1920s. ${ }^{89}$

After the Second World War, it is noticeable that self-repair was initially somewhat absent in the automobile discourse in Germany: magazines published very few articles on the topic. ${ }^{90}$ It was not until 1960 that self-repair regained wider attention in the automobile press. That year the motto "do-it-yourself" appeared for the first time in the $A D A C$ Motorwelt,,${ }^{91}$ and the following year, the new “do-it-yourself" column (mach' es selbst) was introduced, in which even demanding repair jobs such as checking wheel bearings were described. ${ }^{92}$ In 1962, the first in a long series of repair manuals called "Now I help myself" (Jetzt helfe ich mir selbst) appeared on the market. They were written by the well-known automotive journalist Dieter Korp. Each manual was dedicated to a specific car model, and the series sold more than 2.5 million copies until 1975. ${ }^{93}$ Another popular repair manual series, entitled "This is how you do it" (So wird's gemacht), published its first edition in 1966.

The huge success of self-help literature can partly be explained by the accelerating mass motorisation in West Germany from the 1950s onwards. The number of passenger cars went up from 518,000 in 1950 to 3.5 million in 1959 , and

time when automobility was emerging: Borg, Auto Mechanics, ch. "Ad Hoc Mechanics". See also Krebs, "Sobbing, Whining, Rumbling”; id., "Notschrei”.

89 Wetterauer, Andrea: Lust an der Distanz. Die Kunst der Autoreise in der "Frankfurter Zeitung”, Tübingen: Tübinger Vereinigung für Volkskunde 2007; see also Schramm, "Konsumgeschichte".

90 This does not mean that motorists did not repair their cars themselves. It is relatively likely that during the late 1940s and early 1950s, when the supply of spare parts was still difficult, many cars were repaired by their owners. A few repair articles were published, see e.g. Anon.: "Was ist zu tun", in: ADAC Motorwelt 5, 2 (1952), p. 29; Brinzer: "Der Autofriedhof", in: ADAC Motorwelt 8 (1955), p. 335.

91 Anon.: "Wagenpflege leicht gemacht", in: ADAC Motorwelt 13 (1960), p. 272.

92 See e.g. JFD: “mach' es selbst”, in: ADAC Motorwelt 16 (1963), p. 1168.

93 G. W.: “Basteln nach Handbüchern?”, in: ADAC Motorwelt 28, 12 (1975), p. 19-21. 
the total mileage from 5.49 million kilometres in 1953 to 50.3 million in $1959 .{ }^{94}$ One important change in the interwar period was that more members of the lower middle class and working class started to own a car, and many of them first bought a second-hand car. In 1956, 44\% of second-hand cars were bought by workers and employees, but they purchased only $30 \%$ of the new cars sold that year. ${ }^{95}$ In 1961, more used than new cars were sold for the first time: 1.1 to 1 million. ${ }^{96}$ Saving money was often mentioned as the prime reason for buying a second-hand car and carrying out repairs oneself. ${ }^{97}$ After the oil crisis, journalists even diagnosed a "new austerity wave" that led to an increase in demand for second-hand spare parts. ${ }^{98}$

Another more general motive for self-repair can be found in the emerging DIY movement of the 1970 s that encompassed many other craft activities. ${ }^{99}$ The further professionalisation and commercialisation of DIY car repairs can be seen by the opening of garages that rented out lifts and tools and sold spare parts. The oil company Shell had still failed to establish a chain of DIY garages by the mid1960 s, but in the 1970s such garages could be found in many larger cities, and some had up to 70 work spaces. ${ }^{100}$

Saving money was not the only motive for motorists deciding to repair themselves. The self-help literature of the 1960s pointed out that self-repairing not only saved time and money; it was also "fun". ${ }^{101}$ Car maintenance was referred

94 Anon.: Historische Anzahl an Kraftfahrzeugen und Personenkilometer nach KfzTyp in Deutschland in den Jahren 1906 bis 1959, https://de.statista.com/statistik/ daten/studie/249900/umfrage/historische-entwicklung-von-kraftfahrzeugen-in-deutsch land/\#professional (accessed 22.02.2021).

95 König, Das Automobil, p. 127.

96 Anon.: "Die zweite Hand", in: Der Spiegel 22/1961, p. 24-33, here p. 24 and 25.

97 The book cover of the "Jetzt helfe ich mir selbst" book series stated "saves money and time”. See e.g. Korp, Dieter: Jetzt helfe ich mir selbst: VW 1200, Stuttgart: Motor-Presse-Verlag 1965, front cover.

98 STR: "Immer mehr gefragt: Ersatzteile aus zweiter Hand", in: ADAC Motorwelt 28, 2 (1975), p. 4-8.

99 On the German DIY movement see Voges, Jonathan: "Selbst ist der Mann": Do-ityourself und Heimwerken in der Bundesrepublik Deutschland, Göttingen: Wallstein 2017.

100 WM: "Selbstbedienung auch in der Werkstatt?", in: ADAC Motorwelt 25, 8 (1972), p. 59-63.

101 Korp, Dieter: Jetzt helfe ich mir selbst: VW Käfer 1200/1300/1500, Stuttgart: Motorbuch Verlag 1969. 
to as a "hobby", 102 "a lively and gladly practiced "sport"" that compensated for the lack of physical activity in white-collar jobs. ${ }^{103}$ Another author suggested that "noble hobbyists, car enthusiasts and experienced amateur mechanics" would indulge in car repair "out of the pure desire for building and constructing [things]". ${ }^{104}$ Self-help manuals also praised the general understanding of automobile technology as a value in itself; motorists would gain in self-confidence even if they did not plan to get their hands dirty themselves. ${ }^{105}$ There were also plenty of male stereotypes served: ${ }^{106}$ "The child in the man [must] play all his life. Among other things, with a used car!" 107 The ADAC Motorwelt stated that

"[n]o one works on his TV, no one repairs his oil heater, and hardly anyone mends his typewriter. Only with cars do even laymen tinker. And [they do so] with fervour and great joy and without fear of dirt and pinched fingers." 108

Moreover, an advertisement for the mot auto-journal celebrated knowledgeable motorists as being more popular in their circle of friends. ${ }^{109}$ Without any references to the DIY car repair practices of the interwar years, the DIY car repair of the 1970s articulated similar ideas that tinkering with car technology would foster male identities and help to build a distinct collective of knowledgeable motorists.

Market research and opinion polls show that these were not just vain hopes: in the 1969 DIVO survey, car repair ranked seventh in a list of the most popular hobbies. In 1971, an ESSO study found that car repair was a popular recreational activity: three out of ten motorists interviewed said that they repaired many

102 Anon.: So wird's gemacht: VW 1300 und 1200A, Bielefeld and Berlin: Delius, Klasing \& Co. 1966, n. p. [preface].

103 Thaer, Albrecht/Korp, Dieter: Jetzt helfe ich mir selbst: Die Autokarosserie, Stuttgart: Motorbuch Verlag 1975, p. 10.

104 Landgraf, Jahn-Knut: So wird's gemacht: VW 1302/1302 S/1303/1303 S, Bielefeld/Berlin: Delius, Klasing \& Co. 1973, n. p. [preface].

105 Korp, Dieter: Jetzt helfe ich mir selbst: NSU Prinz, Stuttgart: Motorbuch Verlag 1965, p. 9.

106 Anon.: So wird's gemacht: VW 1500/1600, Bielefeld/Berlin: Delius, Klasing \& Co. 1969, n. p. [preface].

107 Lotze, Hedelore: “Das Auto und die Männer”, in: ADAC Motorwelt 7 (1954), p. 711.

108 G. W., "Basteln".

109 mot auto-journal: advertisement, in: Korp, Dieter: Jetzt helfe ich mir selbst: Ford 12 M, Stuttgart: Motorbuch Verlag 1964, n. p. 
things themselves. Moreover, $37 \%$ of car owners attested that car maintenance was a "pleasant" leisure activity. However, the survey also revealed that pleasure and economic necessity often went hand in hand because the wealthier motorists were, the less inclined they were to self-repair. ${ }^{110}$

Car mechanics perceived DIY repairers as unwanted commercial competitors. Already during the professionalisation of the trade in the 1930s, representatives of car mechanics guilds and manufacturers had argued that non-specialist craftsmen and laymen did not possess the necessary knowledge and skills to carry out repairs, and that self-repairs could even harm the operational safety of cars. ${ }^{111}$ In the 1960 s, the authors of self-help guides warned their readers to be careful during the warranty period because self-repairing could cause difficulties for warranty claims. They also emphasised that safety-related repairs, e.g. of brakes, should be left to professional car mechanics. Still, the guides explained how to carry out these repairs. ${ }^{112}$ The representatives of car mechanics went one step further. In 1972, the Central Association of Car Mechanics warned: "the car becomes a weapon [...] when repairs are carried out by laymen, who are often unaware of how fatal mistakes can affect their own and others' safety." 113

The association funded an advertising campaign with the slogan "do-ityourself can be costly". ${ }^{114}$ The German Association for Technical Inspections even lobbied for a ban on DIY car repairs. The well-known DIY magazine "Himself is the Man" (Selbst ist der Mann) countered this as a completely exaggerated criticism, but recognised at the same time that motorists should keep their fingers off the brakes and steering. ${ }^{115}$

\section{CONCLUSION}

To sum up, car repair was not just a means of maintaining technical functionality, and thus facilitating the consumption of (auto-)mobility; it was also an end in itself: repairing one's car fostered one's self-assurance and identity. The emer-

110 WM, "Selbstbedienung".

111 Krebs, "Notschrei".

112 See e.g. Korp, Dieter: "Das kann jeder selber machen”, in: ADAC Motorwelt 21, 1 (1968), p. 38-43; Anon.: "Neue Bücher”, in: ADAC Motorwelt 19, 9 (1966), p. 57.

113 WM, "Selbstbedienung", p. 62.

114 Das Kraftfahrzeug-Gewerbe: advertisement, in: ADAC Motorwelt 25 (1972), n. p.

115 Anon.: "Unser Kommentar", in: Selbst ist der Mann 1/1977, p. 11; see also Haberl, Fritz, "Das Kind nicht mit dem Bade ausschütten”, in: Selbst ist der Mann 10/1977, p. 4. 
gence and expansion of professional repair services facilitated the widespread purchase and use of automobiles during the interwar period and in particular from the late 1950s onwards. In addition, maintenance and self-repair were important moments in the individual and collective appropriation of the motor car. Furthermore, it is interesting to note that the bourgeois self-drivers of the interwar period and the working-class motorists of the 1970s voiced similar arguments for doing-it-yourself: mastering automotive technology was perceived as a way of increasing one's social status. At the same time, there were also significant differences as the DIY repairers of the 1970s were part of a larger DIY movement that reacted to the post-war reduction in working hours and included contradictory elements of progressive environmentalism and petit-bourgeois home cocooning. ${ }^{116}$

For the history of consumption, we can conclude that, until the 1950s, the cost of repairs was a decisive factor in determining who could afford to own a car at all. In addition, the initial unreliability of automobiles was an important argument not to buy a motor car. In other words, increasing the reliability of automotive technology was key for the successful establishment of the automobile consumer sector. This is also true for the emergence and expansion of a proper repair infrastructure that encompassed professional workshops and roadside assistance services. The field of car repair, including self-repair, was central to the emergence and development of automobility. It is likely that other consumer technologies, like radios and TV sets, required similar repair infrastructures, and the history of consumption still lacks a thorough investigation of the role of repair in consuming technology. ${ }^{117}$ Likewise, the history of technology still needs to acknowledge the importance of repair for the diffusion of new consumer technologies. It would be worthwhile taking a second look at questions such as the development of the spare parts and accessories trade, gender roles in repair and self-repair, and the difficult socio-technical relationship between consumers and repairers.

116 Voges, Selbst ist der Mann.

117 See Weber, "Mending or Ending?". 
